\title{
A Development of the High-capacity Data Transmission System on Track Circuit Using Spread Spectrum Communication
}

\author{
Hiroshi MochizukiＳtudent Member （Nihon University, mochi@bit.ecs.cst.nihon-u.ac.jp) \\ Akira Asano Non-member (Kyosan Electric Mfg Co,Ltd.) \\ Minoru Sano Member (Kyosan Electric Mfg Co,Ltd.) \\ Sei Takahashi Member (Nihon University) \\ Hideo Nakamura Member (Nihon University)
}

Keywords: spread spectrum, track circuit, rail noise, orthogonal code, synchronous acquisition

This paper describes the high-capacity data transmission system for advanced ATC (Automatic Train Control) System on track circuit. A conventional ATC system is very high safety, but this system has a problem that the high-capacity data transmission is very hard.It is because track circuit, the object of the data transmission, have some differences with a general communication system, such as the rail noise. On the other hand, spread spectrum (SS) can achieve CDMA (Code Division Multiple Access) that can transmit two or more signals to the same frequency band. Moreover, because this is good also in the characteristic to noise, this is a technique widely used. Then we develop the high-capacity data transmission system using SS communication this time, and we call it SS rail transmission system.

Figure 1 shows SS rail transmission system. According to this figure, in transmitter, the transmission data of the serial is converted into parallel data of the number of multiple-access. After that, this data is modulated by carrier and spread codes, and it is transmitted to track circuit as transmission signal. In receiver, transmission signal to which rail noise is added, and attenuated by track circuit is demodulated by spread code and carrier. Here, orthogonal code is used as spread code. It has the characteristic that there is no cross-correlation under the conditions of synchronisation established between code sequences. Therefore, in SS rail transmission system, CDMA can be achieved by orthogonal code, and the number multiple-access is 63 this time. And SS rail transmission system achieves at about $2000 \mathrm{bps}$ as a whole as about $30 \mathrm{bps}$ a channel.

Basing on above, we carried out computer simulations changed the transmission speed about this system. Figure 2 shows BER characteristic as the result. According to this figure, we verified to be able to take BER of $10^{-5}$ that is the standard of a communication for a railway signal when transmission speed is about $2000 \mathrm{bps}$ that increased to about ten times that of a conventional ATC system.

In addition, we studied about the method of a synchronous acquisition. And we established a good method by giving the same data for a synchronous acquisition to some channels. As a result, we verified to be able to take synchronous acquisition time of about $300 \mathrm{~ms}$ that is a practical level in ATC system.

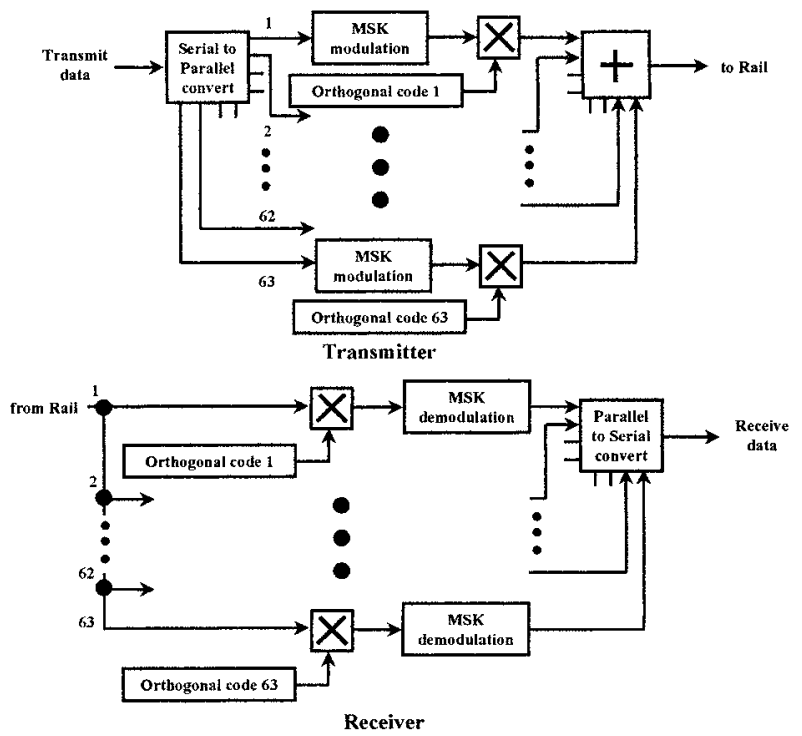

Fig. 1. Block diagram of SS rail transmission system

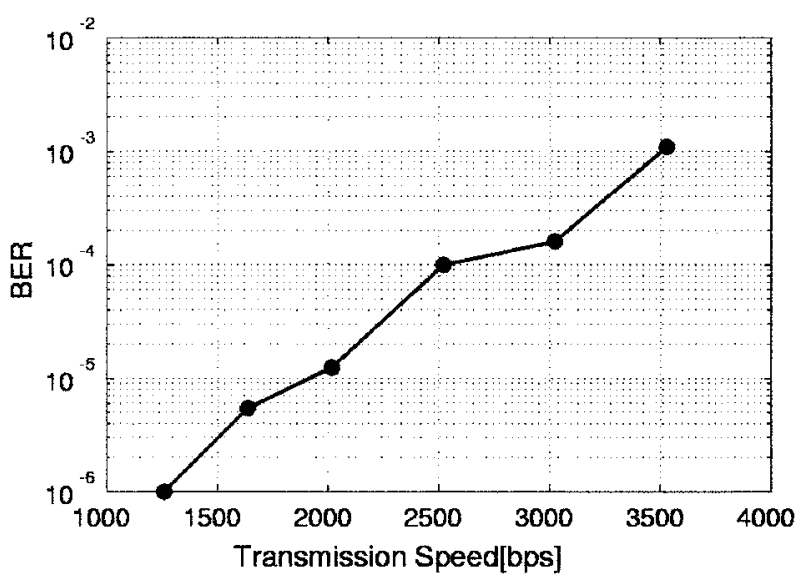

Fig. 2. BER characteristic of SS rail transmission system 


\title{
軌道回路を用いたスペクトラム拡散通信式 多情報伝送システムの開発
}

$\begin{array}{llllll}\text { 学生員 } & \text { 望月 } & \text { 寛* } & \text { 非会員 } & \text { 浅野 } & \text { 晃** } \\ \text { 正 員 佐野 } & \text { 実** } & \text { 正 員 高橋 } & \text { 聖* } \\ \text { 正 員 中村 } & \text { 英夫* } & & & \end{array}$

\section{A Development of the High-capacity Data Transmission System on Track Circuit Using Spread Spectrum Communication}

\begin{abstract}
Hiroshi Mochizuki*, Student Member, Akira Asano**, Non-member, Minoru Sano**, Member,
\end{abstract} Sei Takahashi*, Member, Hideo Nakamura*, Member

This paper describes the high-capacity data transmission system for advanced ATC (Automatic Train Control) System on track circuit. A conventional ATC system is very high safety, but this system has not realized the high-capacity data transmission because of the high return current noise. Therefore, we develop the high-capacity data transmission system using spread spectrum communication in consideration of the characteristic of track circuit. And we verified to be able to take about 2000 bps, with the result that we carried out computer simulations changed the transmission speed about this system. In addition, we studied about the method of a synchronous acquisition. As a result, we established a good method by giving the same data for a synchronous acquisition to some channels. We report this method with result of computer simulations.

キーワード：スペクトラム拡散，軌道回路，電気車雑音，直交符号，同期捕捉

Keywords: spread spectrum, track circuit, rail noise, orthogonal code, synchronous acquisition

\section{1. まえがき}

京浜東北線などで導入されているデジタル ATC (Automatic Train Control) ${ }^{(1)}$ のように，機能の高度化を図った保 安装置の実用化が行われているが，そのベースに情報量の 拡大が寄与している。この情報量がさらに拡大すれば，指 令業務の伝達や設備の状態を反映させた列車制御など従来 の保安制御の概念を大きく変える可能性がある。開発が進 んでいる無線による列車制御システム ATACS (Advanced Train Administration and Communications System) (2) も情 報量は拡大しているが，1列車あたりの情報量にすると極 端に増大しているわけではない。

筆者らは, 現行のデジタル ATCで限界とされている 200〜 $300 \mathrm{bps}$ の約 10 倍となる $2000 \mathrm{bps}$ 程度の情報速度を実現す

\footnotetext{
* 日本大学大学院理工学研究科

干 274-8501 船橋市習志野台 7-24-1

Graduate School of Science and Technology, Nihon University

7-24-1, Narashinodai, Funabashi 274-8501

** 京三製作所

干 230-0031 横浜市鶴見区平安町 2-29-1

Kyosan Electric Mfg Co, Ltd.

2-29-1, Heian-cho, Tsurumi, Yokohama 230-0031
}

るという目標を立て，その手法について検討を行った。当 然のことながら, 鉄道信号システムはフェールセーフ性の 確保が必須である。その点では高周波通過特性に劣るなど 高速伝送に不利な条件があるものの, 無線方式に比べ, 情 報のセキュリテイ確保や妨害などに対する対策も容易で, フェールセーフ性に実績があり，かつ，システム構成その ものを大きく変えることなく実現できる軌道回路を用いた デジタル ATC 型の情報速度の向上というアプローチが妥 当であると考えた。

そこで, 軌道回路を用いた情報伝送の向上というアプロー チに関して, 同一周波数帯でも任意の拡散符号間の直交性を 利用することにより多元接続を行う CDMA (Code Division Multiple Access）を実現できるスペクトラム拡散（Spread Spectrum：以下 SS）通信に着目する。そして, 今回の伝送 対象が，携帯電話で用いられている時のようなマルチユー ザではなく，あくまで地上対車上の 1 対 1 であることから， それらを考慮し軌道回路に適した拡散符号の選定などを行 い, SS 通信によるレール伝送システム (以下 SS 式レール伝 送システム）を提案した。本システムが実用され，2000 bps の伝送が可能となれば，より高度な保安制御の実現に供す る他，指令変更を反映した制御や，災害や異常時を含め機 
器，現場設備の状態に応じた制御など，新しい列車制御の 概念を切り拓く可能性を持っていると考えている。

ATC システムの多情報伝送を目的とした SS 通信による 伝送システムの研究については既に誘導線路を用いた研究 報告があるが(3)，レール間に伝送路を設備せねばならない 問題がある。本研究では, MATLABを用いた計算機シミュ レーションにより，情報速度をパラメータとした時のビッ 卜誤り率特性で拡散符号の選択や利用周波数带域の設定な どを含めた SS 式レール伝送システムを評価し，実用可能 なシステムを提案する。

また，システムの同期捕捉手法については，今回対象と する伝送が地上対車上の 1 対 1 の同期式 CDMA であるこ とに着目し，幾つかのチャネルに同期捕捉用デー夕を与え て行う手法について提案し, その性能についても検討する。

\section{2. レールを用いたデータ伝送の特徵}

$\langle\mathbf{2} \cdot \mathbf{1}\rangle$ 軌道回路 軌道回路は，図 1 のようにある一 定区間でレールを絶縁し，軌道回路送電側（軌道変圧器）と 受電側（軌道リレー）によって作られる閉回路であり，列 車検知センサとしての役割を持つ。

レールには，軌道回路で用いる信号電流の他に大電流の 電気車電流が流れている。信号電流は軌道回路種別により 多様で商用周波数の $1 / 2$ の $25 \mathrm{~Hz}$ から $20 \mathrm{kHz}$ の $\mathrm{AF}$ 带域が 用いられる。また，実際のレールでは，絶縁継目部にイン ピーダンスボンドを付加する。これにより，信号電流に対 してはトランスの働きをして，各軌道回路が独立閉回路を 構成する。一方, 電気車電流に対してはバイパス路として 働き，全ての軌道回路が連続した 1 本の帰線を構成する。

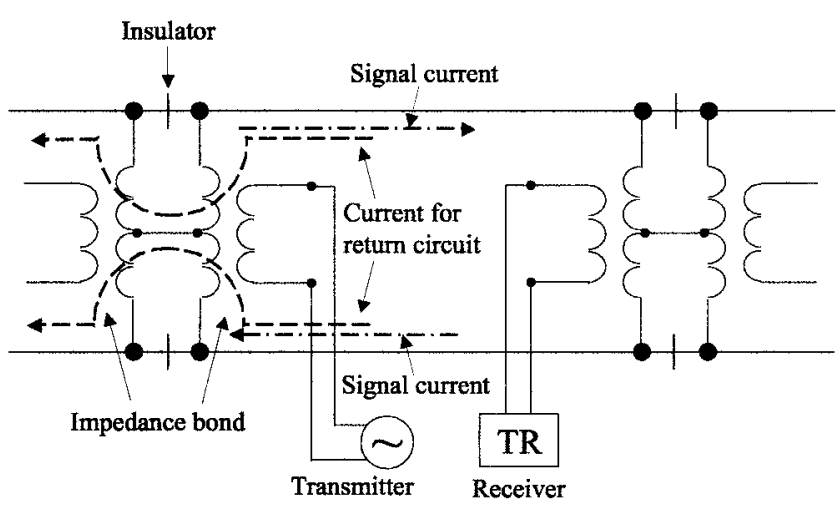

図 1 軌道回路

Fig. 1. Track circuit.

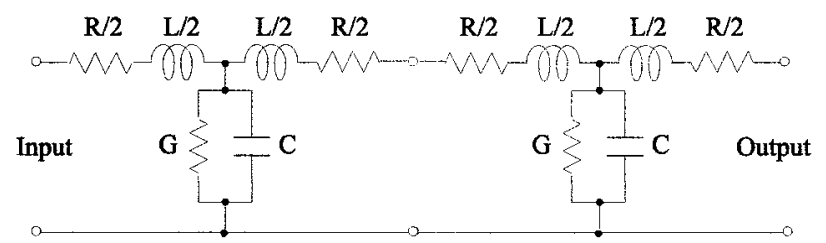

図 2 軌道回路の等価回路

Fig. 2. Equivalent circuit of track circuit.
この軌道回路は送電線路や通信線路と同じように図 2 の ような分布定数回路として考えることができる。軌道回路 は 4 端子回路網として扱うことが一般的であるが, 本論文 では軌道回路計算の簡単化を図るため，図 2 に示すような $\mathrm{T}$ 型回路の形を採用する ${ }^{(4)}$ こここで $R$ をレール抵抗， $L$ を レールインダクタンス， $G$ を漏れコンダクタンス,$C$ を静 電容量と呼び，これらを軌道回路定数といい，その一例を 表 1 に示す。また, この軌道回路定数は, 気象条件により 大きく変動する。特に，漏れコンダクタンスはその変動が 激しく, 降雨, 積雪, 水結の時は漏れコンダクタンスが大 きく, 晴天の時は漏れコンダクタンスが小さい。

実際の軌道回路は数 $100 \mathrm{~m}$ から $1 \mathrm{~km}$ 程度でその周波数 特性は数 $\mathrm{kHz}$ 程度で大きく減衰する低周波通過特性を持っ ている。したがって，一般の通信系と異なり高周波を使う ことができないという特徵を持っている(5)。このため通常 の SS 通信をそのまま用いることはできない。

今回，計算機シミュレーションにより検討を行う際には， この軌道回路をデジタルフィルタにより表現した。その設 計に関しては，図 2 に示すような $\mathrm{T}$ 型回路の形で, 表 1 に 示した軌道回路定数を用いて, 周波数毎の減衰量を計算し, その計算結果を満足するようなフィル夕係数を求めた。そ の周波数特性を図 3 に示す。

以上，軌道回路について述べてきたが，本研究では，直

表 1 軌道回路定数の一例

Table 1. A sample of track circuit constant value.

\begin{tabular}{|c||c|c|c|c|}
\hline $\begin{array}{c}f \\
\mathrm{kHz}\end{array}$ & $\begin{array}{c}R \\
\Omega / \mathrm{km}\end{array}$ & $\begin{array}{c}L \\
\mathrm{mH} / \mathrm{km}\end{array}$ & $\begin{array}{c}G \\
\mathrm{~S} / \mathrm{km}\end{array}$ & $\begin{array}{c}C \\
\mu \mathrm{F} / \mathrm{km}\end{array}$ \\
\hline 0.5 & 1.26 & 1.46 & 0.173 & 2.63 \\
\hline 1 & 1.74 & 1.38 & 0.174 & 1.56 \\
\hline 2 & 2.39 & 1.32 & 0.176 & 1.03 \\
\hline 3 & 2.83 & 1.30 & 0.178 & 0.86 \\
\hline 4 & 3.12 & 1.30 & 0.180 & 0.74 \\
\hline 5 & 3.36 & 1.30 & 0.180 & 0.72 \\
\hline
\end{tabular}
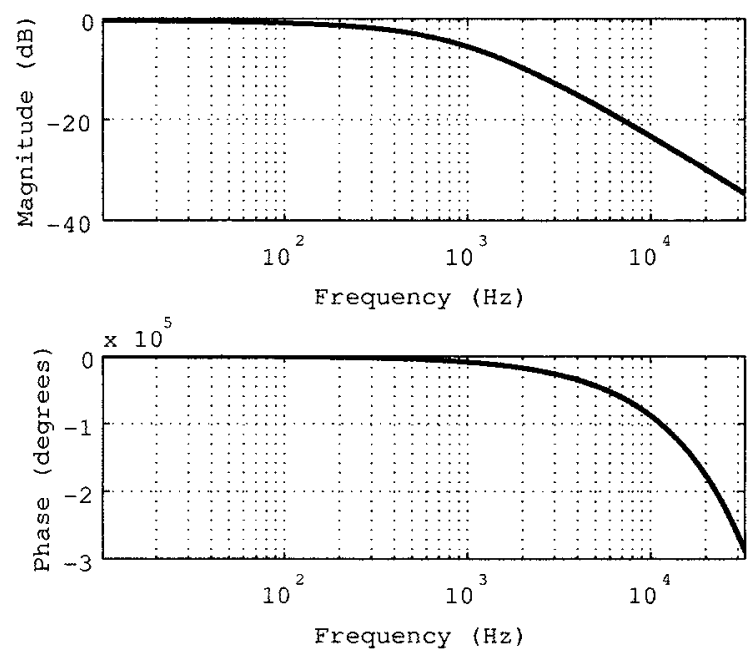

図 3 軌道回路の周波数特性

Fig. 3. Frequency response of track circuit. 
流電化区間のみを対象としている。

$\langle 2 \cdot 2\rangle$ 電気車雑音 電気車雑音として, まず, 電気車 電流雑音が挙げられる。これは, 今回対象として考えてい る直流電化区間において，一般の通信系の白色雑音とは異 なり，電源周波数の 6 次高調波である $300 \mathrm{~Hz}$ 周期で大き なピークを持つような特性を有しており，さらに時間的変 動も大きいという特徴も持っている。なお, 本研究での計 算機シミュレーションによる評価については, 直流電化区 間で実際に測定されたデータを用いている。

その他, 列車の床下に搭載した各機器などから漏洩する 磁束が，軌間に配置した信号設備と結合して影響を与える 直達雑音や，車軸とレール路面の間のアークにより発生す るホイルアーキング雑音も電気車雑音として挙げられる ${ }^{(6)}$ 。

〈2·3〉レールを伝送媒体とすることの利点 今まで 述べてきたように，レールを用いたデータ伝送には，低周 波通過特性に起因する情報伝送速度を大きく取れないこと や電気車雑音への配慮が必要といった固有の問題がある。 しかし，デジタル ATCに代表される列車制御というフェー ルセーフ性が要求されるシステムへの適用においては，情 報のセキュリティ確保や意図的な外乱対策などシステムの 安全性確保への配慮が比較的容易にとれるといった利点も ある。また, 基本構成は現行のデジタル ATC と同じである ので，提案システムの送受信部のみを設計すればよく，増 設する設備が比較的軽微である点からコスト面でも有利で ある。

以上，筆者らが提案する SS 式レール伝送システムの課 題と利点について述べた。

\section{SS 通信の概要}

〈3.1〉原理と特徵図 4 は, SS 通信で一般的に良く 用いられているDS (Direct Sequence：直接拡散）方式の ブロック図である。本方式では，拡散符号による拡散変調 及び逆拡散操作を行うことにより，耐雑音性の向上，通信 の秘匿性, CDMA が実現可能といった特徵がある ${ }^{(7)}$ 。

〈3・2〉 拡散符号に求められる特性 SS 通信における 拡散符号の選択は非常に重要な課題である。拡散符号に求 められる特性としては，以下のようなものが挙げられる。

（1）自己相関特性が符号位相差ゼロで鋭いピークを持 ち，それ以外の任意の符号位相差について絶対值が 十分に小さいこと。

（2）任意の二つの符号について，その相互相関值の絶 対值が全ての符号位相差について十分に小さいこと。

（3）上記条件を満たす符号数が多いこと。

このことを踏まえて, SS 通信に用いられる各種拡散符号 の比較を表 2 に示す。ただし，表中の（）内は同期確立時に おける特性である。表 2 より各種拡散符号の比較を行なう。

まず，M系列（M sequence）について考えると，これは， ある長さのシフトレジスタと原始多項式に基づいたフィー ドバックによって生成される最長の周期となる符号系列で ある。この符号の特徴としては，他の符号に比べ，任意の符

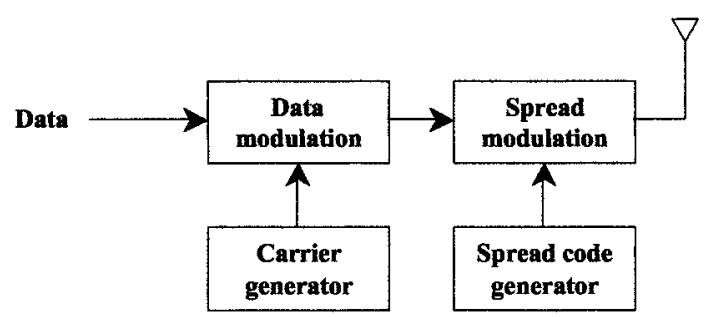

Transmitter

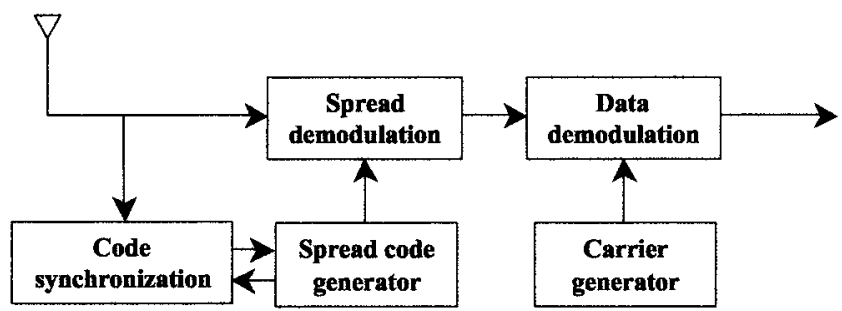

Receiver

図 $4 \mathrm{SS}$ 通信のブロック図 (DS 方式)

Fig. 4. Block diagram of SS communication (DS system).

表 2 各種拡散符号の比較

Table 2. Comparison of each spread code.

\begin{tabular}{|c|c|c|c|}
\hline Spread code & $\begin{array}{l}\text { Auto-correlation } \\
\text { characteristics }\end{array}$ & $\begin{array}{l}\text { Cross-correlation } \\
\text { characteristics }\end{array}$ & $\begin{array}{l}\text { The number of } \\
\text { codes }\end{array}$ \\
\hline M sequence & $\bigcirc(\bigcirc)$ & $\bigcirc(\bigcirc)$ & $\times$ \\
\hline Gold code & $\triangle(\bigcirc)$ & $\triangle(\triangle)$ & $\bigcirc$ \\
\hline Orthogonal code & $\times(\bigcirc)$ & $\times(\bigcirc)$ & $\bigcirc$ \\
\hline
\end{tabular}

( ) : Characteristics under the conditions of synchronisation established between code sequences

号位相差における自己相関及び相互相関特性が良好である ことが挙げられる。たた，その符号数は非常に少なく，ま た符号長を長くしたとしても，その数は必ずしも多くなる とは限らないので，多元接続による情報速度の向上が望め ない。

一方, Gold 符号 (Gold code) は，符号長の等しい2つの $\mathrm{M}$ 系列の加算により得られる合成符号である。この符号の 特徵としては，任意の符号位相差において，ある程度良好 な相関特性を持っている点が挙げられる。また，符号数は (符号長 +2 ) 個あり，これは $\mathrm{M}$ 系列に比べて多い。ただ， 同期確立時における任意の符号間の相互相関特性がゼロで ないため，これらの符号の全てまたはその多くを採用した 多元接続は, ビット誤り率特性の劣化を招くという久点を 持っている。

それらと比較して，直交符号 (orthogonal code) につい て考えると，これは，以下に示すアダマール行列により生 成される。

$$
\begin{aligned}
& H_{1}=[1] \\
& H_{N}=\left[\begin{array}{cc}
H_{N-1} & H_{N-1} \\
H_{N-1} & -H_{N-1}
\end{array}\right] .
\end{aligned}
$$


この (1) 式によって生成された行列の各行が直交符号とし て用いられる。今，符号長 32 の直交符号 32 個について, 任意の自己相関及び相互相関特性を図 5 及び図 6 に示す。 これらの図より，この符号の特徴としては，任意の符号位 相差における自己相関及び相互相関特性は前に述べた $2 つ$ の符号に比べ悪い特性となるが，同期確立時における任意 の符号間の相互相関特性が全てゼロとなり極めて良好な特 性になるという特徵を持っており，また，符号数について は符号長の数だけあるので, 全てのチャネルを同期して送 信する同期式 CDMA という条件下で，多元接続による情 報速度の向上が望める。

以上，各種拡散符号の比較を行ったが，実際には，それ ぞれの伝送における制約条件に合った拡散符号を選択する 必要がある。

〈3・3〉 レール伝送における SS 通信の有効性現在, レール伝送に用いられている MSK 変調では, 時間的変動 の多い電気車雑音が伝送帯域に入ってきた場合，ビット誤 り率特性が劣化してしまう。一方, SS 通信では電気車雑音 の時間的変動があっても，これを拡散符号との相関処理に よって, 使用帯域外へ拡散し, BPFによりカットすること により， S/N 比特性の向上を図ることが可能である。また, 多情報化という点から考えると, 軌道回路の持つ低周波通 過特性から十分な帯域が確保できないため, 同一周波数帯 に複数の信号を伝送することが可能な CDMA を用いるの が有効である。

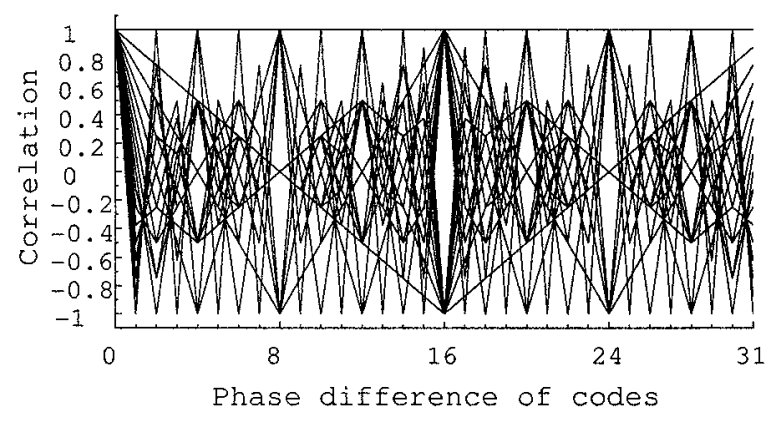

図 5 符号長 32 の直交符号の自己相関特性

Fig. 5. Auto-correlation characteristics of length 32 orthogonal code.

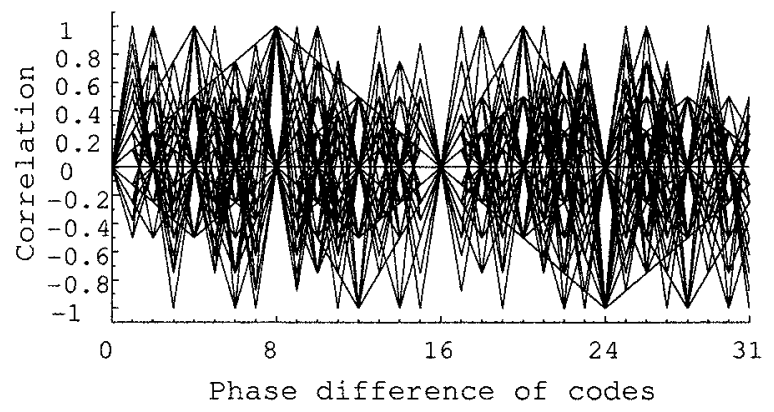

図 6 符号長 32 の直交符号の相互相関特性

Fig. 6. Cross-correlation characteristics of length 32 orthogonal code.
これらを踏まえて, SS 式レール伝送システムに適した拡 散符号について検討する。今回の伝送対象が, 携帯電話で 用いられている時のようなマルチユーザではなく，あくま で地上対車上の 1 対 1 である。したがって, 同期式 CDMA を用いることが可能である。表 2 の各種拡散符号の比較に よると, 直交符号は同期確立時に完全直交性の特徵を持ち, かつ, 符号数が多いため, 狭帯域での多情報化を実現でき る可能性がある。以上のことより，拡散符号として直交符 号を採用する。

さらに，鉄道信号システムはフェールセーフ性の確保が 必須である。これについて検討すると, 本研究で提案する システムの基本構成は, 現行のデジタル ATC と同じ構成を 取り，送受信部における変調方式を工夫しているたけとも 考えられるので, 系としては, 現行と同等のフェールセー フ性を有していると考えられる。ただ，それに加えて，SS 通信における拡散変調は, スペクトラムを広帯域に拡散さ せて実データに拡散符号による一種の暗号化を施している 利点もあるので, その点では, 現行方式より優れている特 長を有している。

以上，レール伝送における SS 通信の有効性を述べたが, 利用周波数帯域の設定など，具体的な設計は次節で述べる。

\section{SS 式レール伝送システム}

$\langle\mathbf{4} \cdot \mathbf{1}\rangle$ 概 要 今回検討する SS 式レール伝送シス テムのブロック図を図 7 に示す。具体的には，送信データ をパラレルデータに変換し, MSK 変調及び拡散変調して, それら全てを足し合わせたものを送信信号として軌道回路 へ流す。軌道回路では, 電気車雑音が付加され, さらに軌 道回路の持つ低周波通過特性により送信信号は減衰する。 受信機では，この信号を各ブロックで逆拡散及び MSK 復 調し，それらのパラレルデータをシリアルデータに変換し

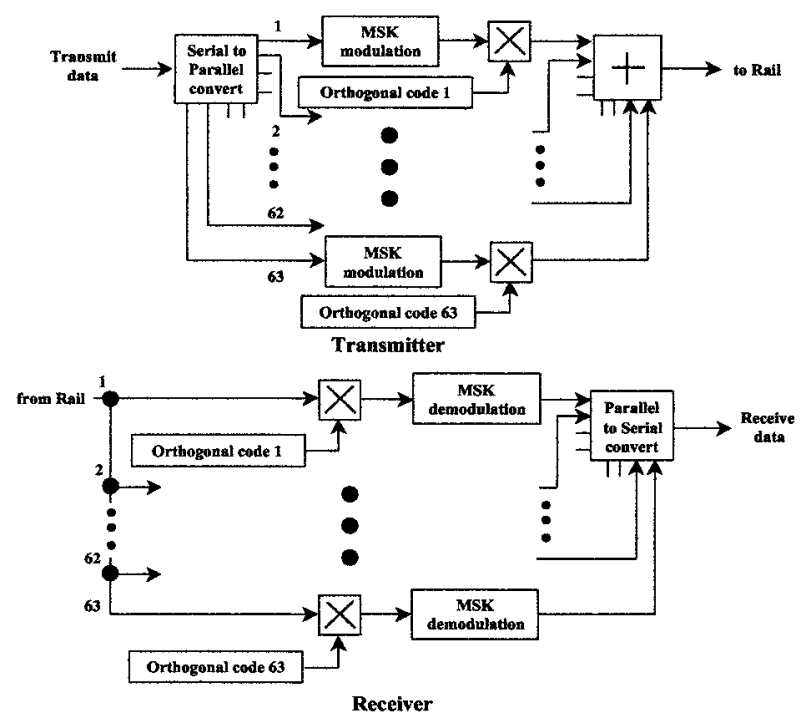

図 7 SS 式レール伝送システムのブロック図

Fig. 7. Block diagram of SS rail transmission system. 
表 3 SS 式レール伝送システムの仕様

Table 3. Specification of SS rail transmission system.

\begin{tabular}{|l|l|}
\hline Parameter & Values \\
\hline Primary modulation & MSK \\
\hline Carrier frequency & $3150 \mathrm{~Hz}$ \\
\hline Spread code & Orthogonal code \\
\hline Code length & 64 \\
\hline The number of multiple access & 63 \\
\hline Track circuit length & $1 \mathrm{~km}$ \\
\hline S/N rate & $17 \mathrm{~dB}$ \\
\hline
\end{tabular}

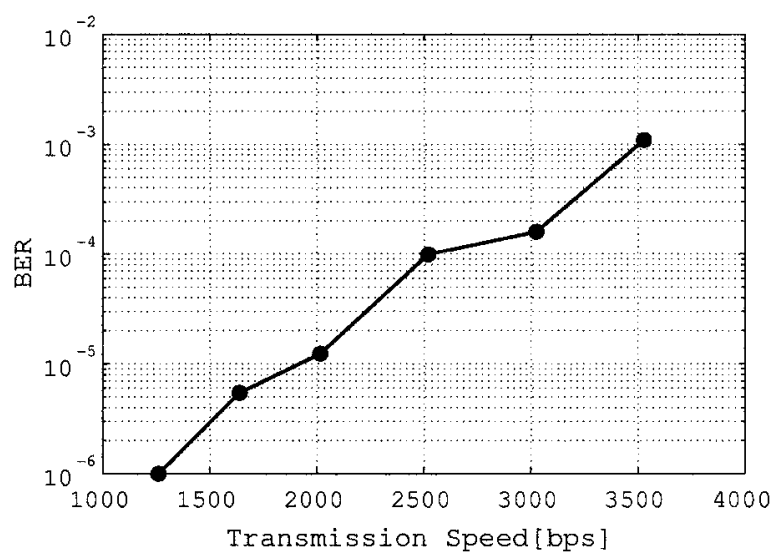

図 $8 \mathrm{SS}$ 式レール伝送システムのビット誤り率特性

Fig. 8. BER characteristic of SS rail transmission system.

て受信データとする。以上, 図 7 に示す本システムはシン プルな構成ながら，前に述べた耐雑音性，秘匿性といった ような SS 通信の優位性を含んでいる。

拡散符号は直交符号を採用しているが，ここで，その符 号長について検討する。ビット誤り率特性のみを考慮する と，雑音をより拡散させるために符号長はできるだけ長く すべきである。しかし一方で，システムの同期捕捉は，拡 散符号のサイクル数に依存する。直交符号では，符号長と 同じ数で多元接続し多情報化を図るため，1 チャネルあた りの情報速度は符号長に反比例する。したがって，同期捕 捉に関しては符号長が短い方が有利となる。これらのこと を踏まえて，500 ms 程度での同期捕捉を実現した上で，本 論文でターゲットとしているシステム全体で $2000 \mathrm{bps}$ 程度 の情報速度とするためには，1 チャネルあたり $30 \mathrm{bps}$ 程度 の 64 チャネルによる CDMA が最適であると考えられるの で，符号長も 64 とする。ただ実際の多元接続は，直交符号 の中に全て 1 という符号が含まれているため，それを除外 して 63 チャネルとする。

以上のことを踏まえて, SS 式レール伝送システムの仕様 を表 3 に示す。

〈4・2〉 計算機シミュレーションによる評価 今まで 行った様々なパラメータの検討の中で, 設計された図 7 や 表 3 に基づいた SS 式レール伝送システムに関して，ここで は,ビット誤り率特性より，その性能を計算機シミュレー ションにより評価する。ただし，本シミュレーションにお いては送受信間の同期が確立しているものとする。
結果として，情報速度をパラメータとした時のビット誤 り率特性を図 8 に示す。図 8 より情報速度を現行システム の約 10 倍となる $2000 \mathrm{bps}$ 程度とした時, 鉄道通信の基準 である $10^{-5}$ のビット誤り率 ${ }^{(8)}$ となっていることが分かる。

\section{5. 同期捕捉手法}

ここでは, SS 式レール伝送システムの同期捕捉手法につ いて検討する。表 2 にも示したように, 今回, 拡散符号と して採用した直交符号は同期確立時には，極めて良好な自 己相関及び相互相関特性を持っている一方で，それ以外の 任意の符号位相差については，それらの相関特性が良好で ないため，システムの同期捕捉については，M 系列のよう に受信信号と拡散符号との相関特性で行なう手法は採用で きず，別の方法を検討する必要がある。

筆者らは, SS 式レール伝送システムの対象とする伝送が 地上対車上の 1 対 1 の通信で，かつ，それが同期式 CDMA で多元接続されていることに着目し，幾つかのチャネルを 組み合わせて，システム全体としての同期捕捉を行なう手 法について検討した。具体的には，幾つかのチャネルに同 じ送信データを伝送し，これを以後，同期捕捉用データと 呼ぶ。受信側では, それらのチャネルに関して任意の符号 位相差で逆拡散操作を行い, 同期捕捉用データの一致判定 を行なう。この時, 各チャネルの同期捕捉用データで不一 致が生じた場合，この不一致を符号位相差ごとにカウント する。そして，この操作を同期捕捉用データ 1 ビットを 1 サイクルとして繰り返していき，ある符号位相差における 同期捕捉用データ不一致が一定のしきい值を超えた時，そ の符号位相差は同期点でないと判定し同期捕捉点の候補か ら削除する。結果として, 唯一, データ不一致が一定のし きい值を超えなかった符号位相差を同期捕捉点として採用 する。

ここで，同期捕捉用チャネルの直交符号の選択について は，同期がとれていない任意の符号位相差において，でき る限りデータの不一致が起こりやすいような組み合わせを 採ることが望ましい。そこで今回，その指標としてビット 誤り指数を定義する。これは 0 。 100 までの值で，送信時 に与えた同期捕捉用データに対して誤りなしは 0 （非反転 出力), 全て誤りは 100 (反転出力) とする。

このことを踏まえて，今，例として直交符号 2，31，38， 47 番目を同期捕捉用チャネルとした時のビット誤り指数の 一例を表 4 に示す。表 4 より，同期捕捉点でない任意の符 号位相差において, max-min 值が大きい, つまり, データ の不一致が起こりやすいということが分かり，短時間で同 期捕捉を実現することができる。実際，この組み合わせは 4 つの直交符号の組み合わせについて全検索した結果，同 期捕捉点以外の任意の符号位相差における max-min 值の最 小值が一番大きくなるような組み合わせである。言い換え ると, 最もデータの不一致が起こる組み合わせであるので, 短時間での同期捕捉の実現が期待できる。

ところで, 表 4 より，この組み合わせにおける，max-min 
表 4 ビット誤り指数の一例

Table 4. A sample of bit error index.

\begin{tabular}{|c|c|c|c|c|c|c|c|}
\hline \multirow{2}{*}{$\begin{array}{c}\text { Phase } \\
\text { difference } \\
\text { of codes }\end{array}$} & \multicolumn{4}{|c|}{ Orthogonal code No. } & \multirow{2}{*}{$\max$} & \multirow{2}{*}{$\min$} & \multirow{2}{*}{$\max -\min$} \\
\hline & 2 & 31 & 38 & 47 & & & \\
\hline 0 & 0 & 0 & 0 & 0 & 0 & 0 & 0 \\
\hline 1 & 100 & 31 & 70 & 45 & 100 & 31 & 69 \\
\hline 2 & 0 & 60 & 45 & 60 & 60 & 0 & 60 \\
\hline 3 & 100 & 67 & 39 & 56 & 100 & 39 & 61 \\
\hline$:$ & \multicolumn{4}{|c|}{. } & \multicolumn{2}{|c|}{ : } & $:$ \\
\hline 31 & 100 & 40 & 24 & 57 & 100 & 24 & 76 \\
\hline 32 & 0 & 0 & 100 & 100 & 100 & 0 & 100 \\
\hline 33 & 100 & 31 & 30 & 66 & 100 & 30 & 70 \\
\hline : & & \multicolumn{2}{|c|}{ : } & : \\
\hline 60 & 0 & 65 & 83 & 60 & 83 & 0 & 83 \\
\hline 61 & 100 & 64 & 41 & 58 & 100 & 41 & 59 \\
\hline 62 & 0 & 64 & 47 & 66 & 66 & 0 & 66 \\
\hline 63 & 100 & 40 & 76 & 44 & 100 & 40 & 60 \\
\hline
\end{tabular}

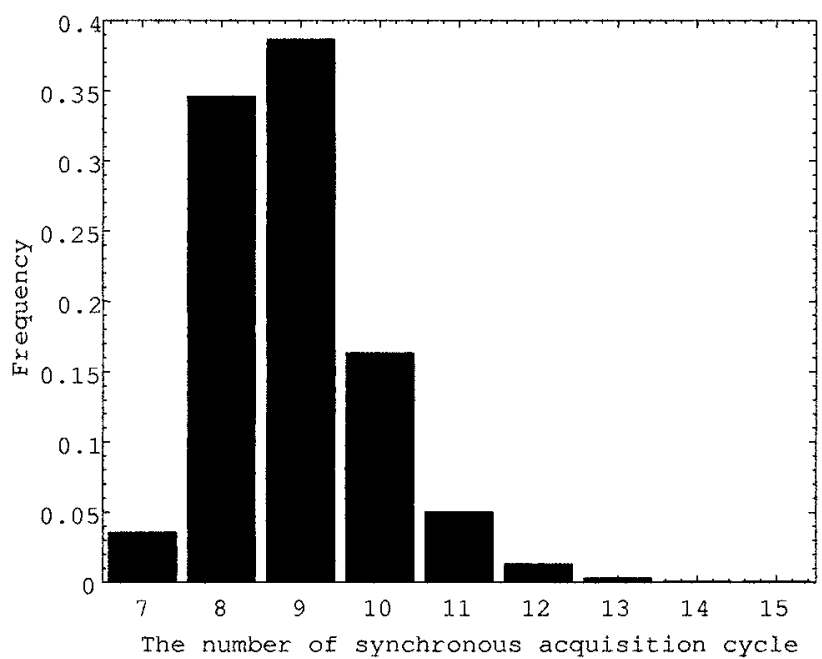

図 9 同期捕捉サイクル数の頻度分布

Fig. 9. Frequency distribution of the number of synchronous acquisition cycle.

值の最小值は符号位相差 61 の時であるが，この時のデー夕 一致確率は全てのビット誤り指数の積と等しく約 0.152 と なる。ここで，本システムでは 1 チャネルあたり約 $30 \mathrm{bps}$ で $500 \mathrm{~ms}$ 程度の同期捕捉をターゲットとしているので，そ れを実現するための拡散符号サイクル数は 15 サイクルとな る。ここで, 同期捕捉点の候補から削除するデー夕不一致の しきい值を 5 とすると， 15 サイクル内でデータ不一致がし きい值の 5 回未満である確率は, 二項定理より約 $7.5 \times 10^{-7}$ となり，十分小さな值になる。したがって，しきい值はこ の值を採用する。

以上，ここまで述べてきた条件を基に，計算機シミュレー ションで得られた同期捕捉サイクル数の頻度分布を図 9 に 示す。図 9 より, 平均 9 サイクル，つまり $300 \mathrm{~ms}$ で，ま た，最悪でも 15 サイクル以内となっているので， $500 \mathrm{~ms}$ 以内での同期捕捉が可能であることを確認した。

\section{6. むすび}

列車制御システムの性能向上を意図して，軌道回路を用 いた対列車情報伝送の伝送速度向上について検討した。既 存の情報伝送速度の限界が 200 300 bps 程度であるのに対 し，筆者らは $2000 \mathrm{bps}$ を目標とした。伝送方式には SS 通 信方式を採用し，その仕様を検討した。伝送媒体となるレー ルは低周波通過特性を持つため軌道回路の信号波は数 $\mathrm{kHz}$ を越えると大きく減衰する。さらに, 軌道回路には電源周 波数の 6 次高調波である $300 \mathrm{~Hz}$ 周期で大きなピークを持 つような電気車雑音が流れるという劣徳な環境にある。こ のような条件を前提とした情報伝送においても，符号長 64 の直交符号を拡散符号とした 63 チャネルの CDMA を採用 することにより，現在，実用化段階にあるデジタル ATCの 約 10 倍となる $2000 \mathrm{bps}$ 程度の情報速度を確保できる可能 性があることを軌道回路特性と実測された電気車雑音を取 り入れた計算機シミュレーションにおいて，ビット䛊り率 特性より確認し，実用化の見通しを検証した。これにより， より高度な保安制御の実現や新しい列車制御の概念を実現 できる可能性を示すことができた。

また，システムの同期捕捉手法については，今回対象と する伝送が地上対車上の 1 対 1 の同期式 CDMA であるこ とに着目し，幾つかのチャネルに同期捕捉用データを与え て行なう手法について提案し，その性能を評価した結果，筆 者らが提案した，ビット誤り指数に基づき算出した同期捕 捉用チャネルである直交符号 $2 ， 31 ， 38 ， 47$ 番目を選択す ることにより，実用レベルである $500 \mathrm{~ms}$ 以下での同期捕捉 が可能であることが確認された。

現在までに，今回の提案手法の送受信部を構成し，実際 に伝送路を用いて計算機シミュレーションの成果の確認を 行っている。今後は，この成果に基づき DSP などによる ハードウェア化の最適化を図り，フィールド試験により性 能評価を行いたい。

(平成 17 年 6 月 28 日受付，平成 17 年 10 月 3 日再受付)

\section{文献}

（1）寺田夏樹：「デジタル ATC」, 日本鉄道電気技術協会, 鉄道と電気技術, Vol.9, No.7, pp.16-17 (1998-7)

(2) ATACS システム評価委員会：「ATACS システム評価委員会 報告 書」, 日本鉄道電気技術協会 $(2005)$

(3) S. Irie and T. Hasegawa: "A study on the Railway Signalling System using Spread Spectrum Communication”, IEICE Technical Report, Vol.93, No.89, pp.43-48 (1993-6) (in Japanese) 入江章二・長谷川孝明：「鉄道信号へのスペクトル搪散通信の適用 に関する一検討」, 信学技報, 93, No.89, pp.43-48 (1993-6)

（4）信号保安協会：鉄道信号ハンドブック,信号保安協会 (1969)

(5) 電気鉄道に扔ける教育調査専門委員会：最新鉄道電気工学, コロナ 社 (2000)

（6）日本鉄道電気技術協会：「昭和 61 年度信号ゼミナール 第 2 編電車 雑音と信号設備への影響」, 昭 61 信号ゼミナール論文集 (1986)

( 7 ) H. Harada and R. Prasad: "Simulation and Software Radio for Mobile Communications", Artech House (2002)

（8）渡辺郁夫・高重哲夫：「ディジタル ATC の情報伝送」, 日本鉄道電気 技術協会, 鉄道と電気技術, Vol.6, No.2, pp.10-14 (1995-2) 


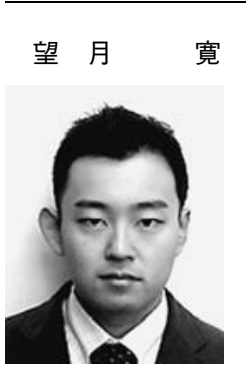

(学生員) 1978 年 10 月 16 日生。 2001 年日大 · 理工·電子工学卒。2003 年同大学院博士前期課程 電子工学専攻了。現在, 同大学院博士後期課程電 子工学専攻在学中。鉄道信号システムに関する研 究に従事。電子情報通信学会学生会員。

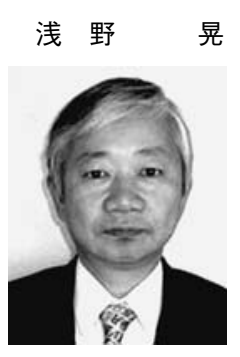

(非会員) 1957 年 5 月 7 日生。 1981 年東京電機 大・工・電気工学卒。現在, (株) 京三製作所に勤 務。鉄道信号システムの開発に従事。

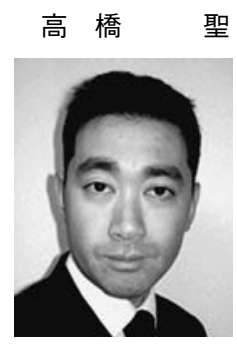

聖（正員）1968 年 8 月 18 日生。1991 年日大 - 理 工·建築卒。1 1993 年同大学院博士前期課程建築学 専攻了。現在, 同大電子情報工学科専任講師。博 士 (工学)。鉄道信号システム, ソフトコンピュー ティングの産業応用に関する研究に従事。電子 情報通信学会, 日本信頼性学会, 日本建築学会各 会員。

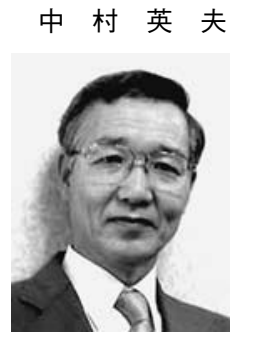

（正員） 1948 年 7 月 12 日生。1971 年国鉄中央鉄 道学園大・電気卒。1972 年鉄道技術研究所, 1978 年日大·委託研究員, 1986 年東京理科大 · 工 II · 電気卒，1990 年鉄道総合技術研究所室長，同年同 退職，日大・理工助教授，現在，同大教授。博士 (工学)。ディペンダブルシステム, 情報応用交通 工学の研究に従事。電子情報通信学会 DC 研究専 門委員会委員，信頼性学会会長，電気学会論文委 員。電子情報通信学会, 日本信頼性学会, 安全工学会, IEEE 各会員。
佐 野

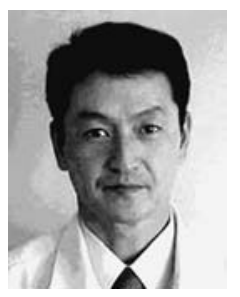

（正員） 1962 年 8 月 28 日生。 1986 年東京電機 大・理工・電気工学卒。現在，(株) 京三製作所信 号事業部信号技術部システムグループ課長。列車 制御のシステム設計に従事。 